\title{
Above- and belowground phytomass and carbon storage in a Belgian Scots pine stand
}

\author{
Ivan A. Janssens ${ }^{a *}$, David A. Sampson ${ }^{\mathrm{a}}$, Jan Cermak ${ }^{\mathrm{b}}$, Linda Meiresonne, \\ Francesca Riguzzid $^{d}$, Stijn Overloop ${ }^{\mathfrak{c}}$, Reinhart Ceulemans ${ }^{\mathrm{a}}$ \\ ${ }^{a}$ Department of Biology, University of Antwerp (UIA), Universiteitsplein 1, B-2610 Antwerpen, Belgium \\ ${ }^{b}$ Institute of Forest Ecology, Mendel Agricultural and Forestry University, 61300 Brno, The Czech Republic \\ ' Institute for Forestry and Game Management, B-9500 Geraardsbergen, Belgium \\ ${ }^{\mathrm{d}}$ Consorzio Agrital Ricerche, 00057 Maccarese, Roma, Italy
}

(Received 8 June 1998; accepted 27 October 1998)

\begin{abstract}
We investigated the storage of carbon $(\mathrm{C})$ in the soil, litter and various phytomass compartments in a 69-year-old Scots pine (Pinus sylvestris L.) stand in the Belgian Campine region, Brasschaat, Belgium. The total amount of $\mathrm{C}$ stored in the stand was $248.9 \mathrm{t} \cdot \mathrm{ha}^{-1}, 47 \%$ of which was in soil organic matter, $11 \%$ in surface litter and $42 \%$ in phytomass. More than $60 \%$ of total $\mathrm{C}$ was stored belowground. Total phytomass $\mathrm{C}$ in the stand was $104 \mathrm{t} \cdot \mathrm{ha}^{-1}$; most phytomass $\mathrm{C}$ was found in the stems (70\%). The root system was very shallow and contained only $14 \%$ of the phytomass $\mathrm{C}$, most of it in the coarse roots. Although total live fine root $(<1 \mathrm{~mm})$ length was high $\left(3.3 \mathrm{~km} \cdot \mathrm{m}^{-2}\right)$, fine roots contributed only $2 \%$ to total phytomass. (C Inra/Elsevier, Paris.)
\end{abstract}

carbon storage / phytomass / Pinus sylvestris / roots / Scots pine

Résumé - Phytomasse aérienne et souterraine et stock de carbone dans un peuplement de pin sylvestre en Belgique. Nous avons étudié le stockage du carbone dans le sol, dans la litière et dans différents compartiments de la phytomasse d'une plantation de pins sylvestre (Pinus sylvestris L.), âgés de 69 ans, localisée à Brasschaat, région de la Campine, Belgique. La quantité totale de carbone stockée au niveau de cette plantation était de $248,9 \mathrm{t} \mathrm{ha}^{-1} .47 \%$ étaient localisés dans la matière organique du sol, $11 \%$ dans la litière, et $42 \%$ dans la phytomasse. Plus de $60 \%$ de la quantité totale de carbone se trouvait dans le sous-sol. La quantité de carbone contenue dans la phytomasse était de $212 \mathrm{t} \mathrm{ha}^{-1}$. La plus grande partie de ce dernier a été trouvé dans les tiges (70 \%). Le système racinaire était très superficiel et ne contenait que $14 \%$ du carbone de la phytomasse, principalement localisé dans les grosses racines. Bien que la longueur des racines fines et vivantes ait été importante $\left(3,3 \mathrm{~km} \mathrm{~m}^{-2}\right)$, elles ne représentaient que $2 \%$ de la phytomasse totale. (@) Inra/Elsevier, Paris.)

stock de carbone / phytomasse / Pinus sylvestris / racines / pin sylvestre

\footnotetext{
* Correspondence and reprints ijanssen@uia.ua.ac.be
} 


\section{INTRODUCTION}

European forest productivity has increased by $18 \%$ over the last 30 years [39]. Much of the increased production can be explained by an expansion of the total forested area $(+10 \%)$ as well as improved management techniques [39]; however individual tree growth rates also appear to have been enhanced over this period [38]. Increased growth rates of trees in the last three decades may be due to the increase in atmospheric $\mathrm{CO}_{2}$ concentration and nitrogen $(\mathrm{N})$ deposition [4], but also to the lengthening of the growing season [24]. Forest ecosystems will continue to be exposed to steadily increasing atmospheric $\mathrm{CO}_{2}$ concentrations and, arguably, changing climate. Therefore, it is likely that the observed enhanced tree growth rates will be sustained over the next few decades [39].

It has become increasingly clear, as the conferences of Helsinki (1993) and Kyoto (1997) have established, that detailed inventories of the carbon (C) storage and sequestration in forest ecosystems are needed. Although forests cover only $20-30 \%$ of the land surface $[1,13]$, they contain over $60 \%$ of the $\mathrm{C}$ stored in the terrestrial biosphere [35]. Minor alterations in the $\mathrm{C}$ input/output balance of forests, especially in relation to supposed changes in climate [14], have the potential to strongly affect atmospheric $\mathrm{CO}_{2}$ concentrations and thus the global carbon cycle $[16,37,41]$. Therefore, the role of forests in the terrestrial $\mathrm{C}$ cycle needs further examination.

More than half of the $\mathrm{C}$ accumulated in forests resides in the soil as organic matter [39]. Globally, soil organic matter content increases with decreasing temperature, increasing precipitation and increasing clay content [36]. At the stand level, soil $\mathrm{C}$ storage depends on the quantity, quality and decomposition of the litter inputs into the forest floor and soil. Litter quality is strongly influenced by site quality, vegetation type and age. These key factors also influence $\mathrm{C}$ sequestration and biomass partitioning. Most of the current available data on $\mathrm{C}$ storage in forests address only aboveground phytomass; important information on belowground phytomass is still largely lacking [47].

Scots pine (Pinus sylvestris L.) forests are the commonest forest type in Europe [39], covering $24 \%$ of the total forested area (about 75 million $\mathrm{km}^{2}$ ). High tolerance to a wide range in soil nutrient and soil moisture conditions probably explains this finding [21]. In the Belgian Campine region, Scots pine is typically planted on strongly leached, nutrient-poor podzol soils that developed under heather ecosystems. Humus formed under these conditions exhibits labile, water-soluble acids that have a podzolising (leaching of humus and nutrients) and acidifying effect on the soil. As such, soil microbial and faunal activity are low, leading to slow decomposition, absence of bioturbation and, subsequently, to an accumulation of a mor holorganic horizon [22, 23]. Immobilisation of large amounts of nutrients in the holorganic litter layer reduces even further the already poor site fertility $[12,32,49]$, thereby decreasing the potential growth and $\mathrm{C}$ sequestration in phytomass of the forest. However, because of the typically large organic C pools and the vast surface area covered, Scots pine forests represent a potentially important reservoir for long-term $\mathrm{C}$ storage.

The objectives of this study were to compile and synthesise phytomass and $\mathrm{C}$ storage in a 69-year-old Scots pine plantation in the Belgian Campine region. Previously gathered data on site quality and aboveground phytomass, as well as new onformation on belowground phytomass, litter and soil organic matter are presented.

\section{MATERIALS AND METHODS}

\subsection{Site description}

This study was conducted in an even-aged, 69-yearold Scots pine plantation, part of a 150 ha mixed coniferous/deciduous forest (De Inslag) in Brasschaat $\left(51^{\circ} 18^{\prime} 33^{\prime \prime} \mathrm{N}, 4^{\circ} 31^{\prime} 14^{\prime \prime} \mathrm{E}\right)$, in the Belgian Campine region. The stand is part of the European Ecocraft and Euroflux networks, and is a level II observation plot of the European programme for intensive monitoring of forest ecosystems (EC regulation $n^{\circ} 3528 / 86$ ), managed by the Institute for Forestry and Game Management (Flanders, Belgium). Mean annual temperature at the site is $9.8^{\circ} \mathrm{C}$, with, respectively, $3{ }^{\circ} \mathrm{C}$ and $18{ }^{\circ} \mathrm{C}$ as mean temperatures of the coldest and warmest months. Mean annual precipitation is $767 \mathrm{~mm}$. The study site has an almost flat topography, very gently sloping $(0.3 \%)$, and is at an elevation of $16 \mathrm{~m}$. An overview of the main stand inventory data (1995) is presented in table $I$ and figure 1 .

The forest canopy is rather sparse, with a projected surface area of $65 \%$ [44] and a projected leaf area index (LAI) between 2.1 and 2.4 [11]. The vigorous undergrowth of Prunus serotina Ehrh. and Rhododendron ponticum L. was completely removed in 1993, giving way to a moss layer dominated by Hypnum cupressiforme Hedw. There are only two needle classes (current and last year's needles). Needle analysis (table II) has shown the stand to be poor in magnesium $(\mathrm{Mg})$ and phosphorus $(P)[34,44]$. Needle nitrogen concentrations were optimal, probably because the site is located in an 
Table I. Summary of stand inventory data.

\begin{tabular}{lccc}
\hline Stand characteristic & Value & Units & Reference \\
\hline Mean DBH & 0.27 & $\mathrm{~m}$ & {$[8]$} \\
Mean tree height & 20.6 & $\mathrm{~m}$ & {$[8]$} \\
Mean canopy depth & 3.7 & $\mathrm{~m}$ & {$[8]$} \\
LAI & $2.1-2.4$ & & {$[11]$} \\
Density & 556 & trees $^{-h^{-1}}$ & \\
Basal area & 31.2 & $\mathrm{~m}^{2} \cdot \mathrm{ha}^{-1}$ & {$[8]$} \\
Standing wood volume & 298.5 & $\mathrm{~m}^{3} \cdot \mathrm{ha}^{-1}$ & {$[8]$} \\
Wood volume increment & & & \\
1988-1995 & 8.1 & $\mathrm{~m}^{3} \cdot \mathrm{ha}^{-1} \cdot$ year $^{-1}$ & {$[27]$} \\
1995-1998 & $6-7$ & $\mathrm{~m}^{3} \cdot \mathrm{ha}^{-1} \cdot$ year $^{-1}$ & (Meiresonne, \\
& & & unpublished) \\
Mean height growth & 0.12 & $\mathrm{~m}^{-y_{e a r}}$ & {$[27]$} \\
C/N young needles & 23.4 & & {$[34]$} \\
N/P young needles & 16.8 & & {$[34]$} \\
\hline
\end{tabular}

All data from [8] were collected in 1995; leaf area index (LAI) was measured in 1996-1997 with a LCA-2000 (Licor, USA). DBH: diameter at breast height.

area with high $\mathrm{NO}_{\mathrm{X}}$ and ammonia deposition (30$40 \mathrm{~kg} \cdot \mathrm{ha}^{-1} \cdot$ year $\left.^{-1}\right)[26]$.

The upper soil layer is ca. $1.8 \mathrm{~m}$ thick and consists of aeolian northern Campine cover sand (Dryas III). Beneath this sand layer, at a depth of 1.5 to $2 \mathrm{~m}$, lies a clay layer (Tiglian) and deeper down another sand layer (sands of Brasschaat, Pretiglian) [3]. The stand has been described as a moderately wet sandy soil with a distinct humus and/or iron B horizon. The soil type is a psammentic haplumbrept (United States Department of Agriculture classification) or a haplic podzol (Food and Agriculture Organisation classification) [3]. A more detailed description of the topsoil profile with texture analysis and $\mathrm{pH}$ for all horizons is given in table III. The site has poor drainage due to the clay layer. The soil is moist but rarely saturated, and has a high hydraulic conductivity in the upper layers (sand). Groundwater normally is at 1.2 to $1.5 \mathrm{~m} \mathrm{[3]}$. The low pH values (table III) indicate that the soil is in the aluminium buffer region [42]. In this buffer region, base cation absorption is reduced and base cations are subject to leaching [40]. This could in part explain the low $\mathrm{Mg}$ content of the needles (table II). In these acid conditions, polymeric Alhydroxy cations are being produced that block the free exchange sites on the clay minerals and organic matter particles. This further reduces the already poor cation exchange capacity (table IV). Another feature of the aluminium buffer region is the precipitation of $\mathrm{Al}$ and $\mathrm{Fe}$ phosphates [20], which strongly reduces $P$ availability and may be responsible for the low $\mathrm{P}$ concentrations in the needles (table II).

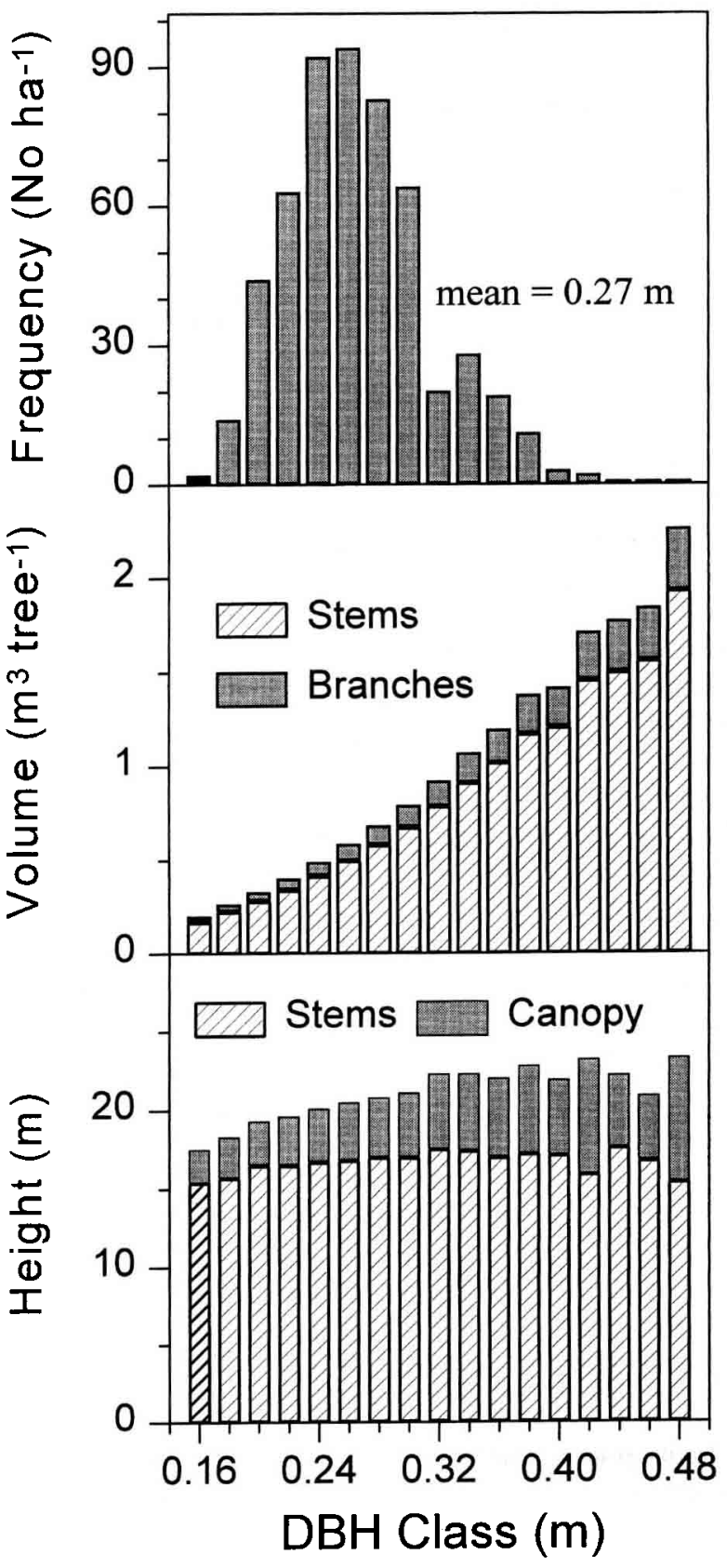

Figure 1. Top: Frequency distribution of diameter at breast height $(\mathrm{DBH})$ classes (measured at $1.3 \mathrm{~m}$ ). Middle: Mean stem and branch volume for the different DBH classes. Bottom: Mean stem and canopy height for the different DBH classes (modified after [8]). 
Table II. Nutrient concentrations in the soil, litter layer and needles in the forest stand [34].

\begin{tabular}{|c|c|c|c|c|c|c|c|c|c|}
\hline & $\mathrm{Na}$ & $\mathrm{K}$ & $\mathrm{Ca}$ & $\mathrm{Mg}$ & $\mathrm{Fe}$ & $\mathrm{Al}$ & $\mathrm{N}$ & $\mathbf{P}$ & $\mathrm{S}$ \\
\hline \multicolumn{10}{|l|}{ Needles } \\
\hline Optimal & & $>7000$ & $>2000$ & $>1000$ & & & $>18000$ & $>1700$ & \\
\hline $1^{\text {st }}$ year & 155 & 7256 & 1841 & 723 & 84 & 153 & 20593 & 1226 & 5044 \\
\hline $2^{\text {nd }}$ year & 467 & 5269 & 3042 & 688 & 131 & 175 & 21751 & 1084 & 5240 \\
\hline \multicolumn{10}{|l|}{ Litter } \\
\hline $\mathrm{O}^{\mathrm{F}}+\mathrm{O}^{\mathrm{H}}$ & 90 & 420 & 1860 & 310 & 3140 & 1030 & 13010 & 446 & 1535 \\
\hline \multicolumn{10}{|l|}{ Soil } \\
\hline Al & 40 & 204 & 92 & 124 & 2669 & 1527 & 1021 & 76 & 30 \\
\hline Ap & 23 & 164 & 52 & 111 & 2355 & 1586 & 457 & 41 & 30 \\
\hline $\mathrm{A} / \mathrm{E} / \mathrm{Cg}$ & 23 & 239 & 57 & 131 & 5288 & 1826 & 164 & 15 & 33 \\
\hline $\mathrm{Cg}$ & 32 & 954 & 33 & 440 & 6918 & 4527 & 167 & 21 & 67 \\
\hline
\end{tabular}

All units are $\mathrm{mg} \cdot \mathrm{kg}^{-1} \mathrm{dry}$ matter. Optimal values are taken from $[45,46]$ and are valid only for current year $\left(1^{\mathrm{st}}\right.$ year $)$ needles.

Table III. Depth, pH, texture analysis, bulk density, $\mathrm{C}$ concentration and $\mathrm{C}$ storage to a depth of $1 \mathrm{~m}$ in all soil horizons at the forest stand $[3,10,23]$.

\begin{tabular}{lccccccccc}
\hline Horizon & $\begin{array}{c}\text { Depth } \\
(\mathrm{cm})\end{array}$ & $\begin{array}{c}\mathrm{pH} \\
\left(\mathrm{H}_{2} \mathrm{O}\right)\end{array}$ & $\begin{array}{c}\mathrm{pH} \\
\left(\mathrm{CaCl}_{2}\right)\end{array}$ & $\begin{array}{c}\text { Clay } \\
(\%)\end{array}$ & $\begin{array}{c}\text { Loam } \\
(\%)\end{array}$ & $\begin{array}{c}\text { Sand } \\
(\%)\end{array}$ & $\begin{array}{c}\text { Bulk Density } \\
\left(\mathrm{g} \cdot \mathrm{cm}^{-3}\right)\end{array}$ & $\begin{array}{c}\% \mathrm{C} \\
(\mathrm{wt} . \%)\end{array}$ & $\begin{array}{c}\text { Total C } \\
\left(\mathrm{t} \cdot \mathrm{ha}^{-1}\right)\end{array}$ \\
\hline Litter & $-6-0$ & 3.9 & 3.3 & & & & & & \\
$\mathrm{~A} 1$ & $0-2$ & & 3.0 & 6.2 & 13.0 & 80.8 & 1.21 & 8.99 & 21.8 \\
$\mathrm{Ap}$ & $2-34$ & 3.8 & 3.3 & 4.2 & 6.9 & 88.9 & 1.363 & 1.12 & 48.9 \\
$\mathrm{~A} / \mathrm{E} / \mathrm{Cg}$ & $34-50$ & 4.1 & 3.7 & 2.1 & 9.2 & 88.8 & 1.543 & 0.75 & 18.5 \\
$\mathrm{Cg}$ & $50-90$ & 4.1 & 3.8 & 1.1 & 0.8 & 98.1 & 1.549 & 0.33 & 20.7 \\
$2 \mathrm{CBhg}$ & $90-100$ & 4.1 & 3.8 & & & & 1.555 & 0.31 & 4.8 \\
& & & & & & & & Total & 114.7
\end{tabular}

Table IV. Effective cation exchange capacity (CEC eff), total cation exchange capacity (CEC tot), CEC eff/CEC tot ratio, effective base saturation (BS eff) and total base saturation (BS tot) at three depths in the soil [44].

\begin{tabular}{lccccc}
\hline Depth $(\mathrm{cm})$ & CEC eff & CEC tot & CEC eff/tot & BS eff & BS tot \\
\hline 10 & 0.9 & 3.1 & 0.28 & 17.5 & 5.0 \\
30 & 1.0 & 2.0 & 0.50 & 31.3 & 15.7 \\
50 & 1.0 & 1.2 & 0.85 & 20.9 & 17.8 \\
Mean & 1.0 & 2.1 & 0.55 & 23.2 & 12.8 \\
\hline
\end{tabular}

$\mathrm{CEC}$ is in meq $100 \mathrm{~g}^{-1}$ and BS in \%; effective values were measured at the prevalent soil $\mathrm{pH}$ and total values were measured at $\mathrm{pH}=7$. 


\subsection{Standing phytomass}

\subsubsection{Stems}

Total stemwood volume ( $7 \mathrm{~cm}$ diameter height) was calculated from the 1995 stand inventory data [8]. We measured wood density $(n=13)$ and C concentration (see later) $(n=53)$ to convert volume estimates to $C$ equivalents.

\subsubsection{Needles}

Six trees (representative for the site) were selected according to the technique by Cermak and Kucera [7]. An allometric estimate of needle biomass was obtained from a destructive harvest of these six trees, using the equation:

$$
Y=-0.4908+0.0433 X-0.0003 X^{2}
$$

[8] where $Y=$ needle biomass $(\mathrm{kg})$ and $X=$ diameter at breast height $(\mathrm{DBH} ; \mathrm{cm})\left(R^{2}=0.965\right)$. This equation was applied to each tree in the stand to obtain total stand needle biomass. Needle $\mathrm{C}$ storage at stand level was calculated by multiplying needle biomass with the mean needle $\mathrm{C}$ concentration $(n=12)$.

\subsubsection{Branches}

No statistically significant correlation between branch biomass and stem biomass of the six harvested trees was found, which was probably related to the small sample size. We therefore used the mean ratio of branch weight to stem weight $(=0.175)$ to scale up branch biomass to the stand level. $\mathrm{C}$ storage in the branches was calculated from the $\mathrm{C}$ concentration of the branches $(n=12)$.

\subsubsection{Coarse roots}

We excavated the root systems of four recently deceased trees in 1997 to establish a site-specific allometric relation between DBH and coarse root ( $>5 \mathrm{~mm}$ ) biomass. A linear regression between coarse root biomass and $\mathrm{DBH}^{3}$ was used to scale up to the stand level. Root $\mathrm{C}$ concentration (four pooled samples) was used to estimate stand level coarse root $C$ content.

\subsubsection{Fine and medium roots}

Fine $(<1 \mathrm{~mm})$ and medium $(1-5 \mathrm{~mm})$ root biomass was estimated by core sampling $[30,33]$ in January $(n=15)$ and May $(n=15)$ 1997. Intact litter columns (down to the mineral layer) were excavated using a sharp-edged metal cylinder (inner diameter of $12 \mathrm{~cm}$ ).
One half was used to assess fine root biomass and the other half to determine total litter mass. Fine root biomass in the soil underlying the removed litter columns was estimated using a soil corer (inner diameter of $8 \mathrm{~cm}$; Eijkelkamp, The Netherlands). Intact $15-\mathrm{cm}$ increments were removed to a depth of $90 \mathrm{~cm}$. Samples from different depths were assessed separately $(0-5,5-15,15-30$, $30-45,45-60$ and $60-90 \mathrm{~cm}$ ). Root fragments were removed from the samples, washed and sorted into three diameter classes: $0-1,1-2$ and $2-5 \mathrm{~mm}$. Live and dead root fragments were subsequently separated by visual inspection as described by Persson [31] and Vogt and Persson [48]: the xylem of dead roots looks darker and deteriorated, the degree of cohesion between the cortex and periderm decreases and root tips become brittle and less resilient. Total root length of each sample was measured using a portable laser area meter modified for root lengths (CI-203RL, Cid Inc., Vancouver USA). Dry mass $\left(24 \mathrm{~h}\right.$ at $\left.80^{\circ} \mathrm{C}\right)$ and ash content $\left(5 \mathrm{~h}\right.$ at $\left.550^{\circ} \mathrm{C}\right)$ of each sample was determined. Ash-free fine root biomass was used to avoid contamination by mineral soil particles [2]. Fine root $C$ content for each diameter class was estimated from standing biomass and $\mathrm{C}$ concentration $(n=4)$.

\subsection{Surface litter}

\subsubsection{Holorganic horizon}

The total mass of organic matter in the holorganic horizon was estimated from the 30 subsamples taken from the litter columns (see earlier). We assumed an equal fine root biomass in each half of the litter column. This amount was subtracted from the total litter dry mass $\left(24 \mathrm{~h}\right.$ at $\left.80^{\circ} \mathrm{C}\right)$ to obtain an estimate of the total organic matter in the litter layer. The $\mathrm{O}^{\mathrm{L}}$ horizon (fresh litter) of each sample was separately assessed from the $\mathrm{O}^{\mathrm{F}}+\mathrm{O}^{\mathrm{H}}$ layers (decomposing litter). $\mathrm{C}$ concentrations of each litter sample $(n=2)$ were used to convert total dry mass to C content.

\subsubsection{Coarse woody debris}

The amount of dead wood ( $>5 \mathrm{~mm}$ in diameter) at the soil surface was assessed in 1997 in five randomly selected subplots of varying area. We used 1-, 25- and $100-\mathrm{m}^{2}$ plots to sample branches with diameters of respectively $0.5-2.5,2.5-5$ and $>5 \mathrm{~cm}$. All branches were taken to the laboratory, dried $\left(2\right.$ weeks at $\left.80^{\circ} \mathrm{C}\right)$, weighed and analysed for $C$. For the logs, eight $400 \mathrm{~m}^{2}$ plots were sampled. The volume of all logs was calculated, and density and $\mathrm{C}$ concentration were determined on two to three subsamples per log. 


\subsection{Mineral soil}

\subsubsection{Soil organic matter}

Fifteen, 1-m deep soil cores were taken to estimate the organic matter content of each horizon in the soil profile. All samples were dried, sieved (mesh $=2 \mathrm{~mm}$ ), ground and analysed for $\mathrm{C}$. Total $\mathrm{C}$ content in each horizon $\left(\mathrm{t} \cdot \mathrm{ha}^{-1}\right)$ was calculated from the layer thickness, bulk density and $\mathrm{C}$ concentration (table III).

\subsubsection{Belowground litter}

The amount of dead roots in the soil, obtained while sampling fine root biomass, was used as an estimate for belowground litter. $\mathrm{C}$ content was determined for the different diameter classes from their $\mathrm{C}$ concentrations $(n=3)$.

\subsection{Chemical analysis}

Estimating $\mathrm{C}$ storage in phytomass compartments requires information on both total phytomass and $\mathrm{C}$ concentration in the different tissues. Although data from the literature were available on the $C$ concentrations in the phytomass compartments, these data cover quite a wide range (e.g. 45-54\% in Scots pine needles in Belgium [44]) and could lead to serious over- or underestimations of total $\mathrm{C}$ content. We therefore chose to perform chemical analysis on each of the $C$ pools at the site.

All $\mathrm{C}$ analyses used in the budgets were made using the dry combustion technique, except for the soil analyses, which were determined by wet oxidation (dichromate) of organic matter followed by colorimetric determination of the chromic produced [28]. All soil, litter and needle mineral analyses in table $I$ were performed following the procedures of Cottenie et al. [9].

\section{RESULTS}

\subsection{Standing phytomass}

Total stemwood volume was $298.5 \mathrm{~m}^{3} \cdot \mathrm{ha}^{-1}$ [8], with an average density of $0.502 \mathrm{~g} \cdot \mathrm{cm}^{-3}$. Stem biomass totalled $149.9 \mathrm{t} \cdot \mathrm{ha}^{-1}$, with a total $\mathrm{C}$ content of $73.3 \mathrm{t} \cdot \mathrm{ha}^{-1}$ (table $V$ ). Branch mass was $26.2 \mathrm{t} \cdot \mathrm{ha}^{-1}$, representing a $\mathrm{C}$ pool of $13.5 \mathrm{t} \cdot \mathrm{ha}^{-1}$ (table $\mathrm{V}$ ). Needle biomass was $6.3 \mathrm{t} \cdot \mathrm{ha}^{-1}[8]$; total $\mathrm{C}$ storage in the needles was $3.0 \mathrm{t} \cdot \mathrm{ha}^{-1}$.
All harvested Scots pines had surprisingly shallow rooting depths, and none exhibited a tap root. These data are consistent with results from the same stand presented by Cermak et al. [8]. In their study (seven wind-toppled trees), the mean depth of the coarse root system was $1.04 \mathrm{~m}$ and the projected root area was $29.9 \mathrm{~m}^{2}$. The allometric relation between DBH and coarse root $(>5 \mathrm{~mm}$ ) biomass obtained in this study was:

$$
Y=22.47+1020.2 X
$$

where $Y=$ coarse root biomass $(\mathrm{kg})$ and $X=\mathrm{DBH}^{3}(\mathrm{~m})$ $\left(R^{2}=0.69\right)$. Total coarse $(>5 \mathrm{~mm})$ root biomass was $23.9 \mathrm{t} \cdot \mathrm{ha}^{-1}$, with a total C storage of $11.8 \mathrm{t} \cdot \mathrm{ha}^{-1}$ (table $\mathrm{V}$ ). Fine root biomass did not differ between January and May. The majority of the live fine $(<1 \mathrm{~mm})$ roots was found in, and just below, the holorganic horizon, and maximum root density shifted downwards from fine to medium roots (figure 2). Biomass of both live and dead fine $(<1 \mathrm{~mm})$ roots over the total investigated rooted soil was much higher than that of medium size roots (1-2 and 2-5 mm) (figure 3). This difference was completely situated in the upper $15 \mathrm{~cm}$ of the soil (figure 2). Few fine roots were found below $60 \mathrm{~cm}$. For the smallest size class $(<1 \mathrm{~mm})$, specific root length was $10.2 \mathrm{~m} \cdot \mathrm{g}^{-1}$, and total root length was $3.3 \mathrm{~km} \cdot \mathrm{m}^{-2}$. No correlation with the distance from the nearest tree (or trees) was detected. C storage was $1.8 \mathrm{t} \cdot \mathrm{ha}^{-1}$ in the fine roots and $1.0 \mathrm{t} \cdot \mathrm{ha}^{-1}$ in the medium roots (table $V$ ).

Total phytomass contained only $42 \%$ of the total amount of $C$ stored in the ecosystem (figure 4). Most of the phytomass $C$ was stored in the stems $(70 \%)$, and no more than $14 \%$ was stored in the belowground biomass (figure 4).

\subsection{Surface litter}

The amount of organic matter in the holorganic horizon (not including live roots) was $73.1 \mathrm{t} \cdot \mathrm{ha}^{-1}$. Most of this dry matter $(85 \%)$ was stored in the $\mathrm{O}^{\mathrm{F}}+\mathrm{O}^{\mathrm{H}}$ layer, representing a $\mathrm{C}$ pool of $20.6 \mathrm{t}^{\mathrm{h}} \mathrm{ha}^{-1}$ (table $V$ ). The upper layer of the holorganic horizon, the $\mathrm{O}^{\mathrm{L}}$ layer, had a carbon content of $4.9 \mathrm{t} \cdot \mathrm{ha}^{-1}$ (table $\mathrm{V}$ ).

As could be expected for a managed plantation, the amount of coarse woody debris (in various stages of fragmentation or decomposition) was rather small. Total dry matter was $2.8 \mathrm{t} \cdot \mathrm{ha}^{-1}, 40 \%$ of which was found in logs, and another $40 \%$ was found in twigs and small branches $(<2.5 \mathrm{~cm})$. C storage in dead wood was $1.3 \mathrm{t} \cdot \mathrm{ha}^{-1}$ (table $V$ ). The total surface litter $\mathrm{C}$ pool contained $26.8 \mathrm{t} \cdot \mathrm{ha}^{-1}$, representing $11 \%$ of the $\mathrm{C}$ accumulated in the stand (figure 4). 
Table V. Biomass, $\mathrm{C}$ concentration (wt \%) and $\mathrm{C}$ storage $\left(\mathrm{t} \mathrm{ha}^{-1}\right)$ in the phytomass, surface litter and soil compartment of the pine ecosystem.

\begin{tabular}{|c|c|c|c|}
\hline & Pool size $\left(\mathrm{t} \cdot \mathrm{h} \mathrm{a}^{-1}\right)$ & $\mathrm{C}$ concentration (wt. \%) & C storage $\left(\mathrm{t} \cdot \mathrm{ha}^{-1}\right)$ \\
\hline \multicolumn{4}{|l|}{ Soil } \\
\hline Organic matter & & & 114.7 \\
\hline Root litter & 6.4 & & 3.0 \\
\hline Subtotal soil & & & 117.7 \\
\hline \multicolumn{4}{|l|}{ Surface litter } \\
\hline $\mathrm{O}^{\mathrm{L}}$ layer & 10.8 & 45.9 & 4.9 \\
\hline $\mathrm{O}^{\mathrm{F}}+\mathrm{O}^{\mathrm{H}}$ layers & 62.3 & 33.0 & 20.6 \\
\hline Woody debris & 2.8 & & 1.3 \\
\hline Subtotal litter & 75.9 & & 26.8 \\
\hline \multicolumn{4}{|l|}{ Phytomass } \\
\hline Stems & 149.9 & 48.9 & 73.3 \\
\hline Branches & 26.2 & 51.6 & 13.5 \\
\hline Needles & 6.3 & 48.2 & 3.0 \\
\hline Coarse roots (> $5 \mathrm{~mm})$ & 23.9 & 49.4 & 11.8 \\
\hline Medium roots $(1-5 \mathrm{~mm})$ & 2.0 & 52.6 & 1.0 \\
\hline Fine roots $(<1 \mathrm{~mm})$ & 3.2 & 55.4 & 1.8 \\
\hline Subtotal phytomass & 211.5 & & 104.4 \\
\hline Total & & & 248.9 \\
\hline
\end{tabular}

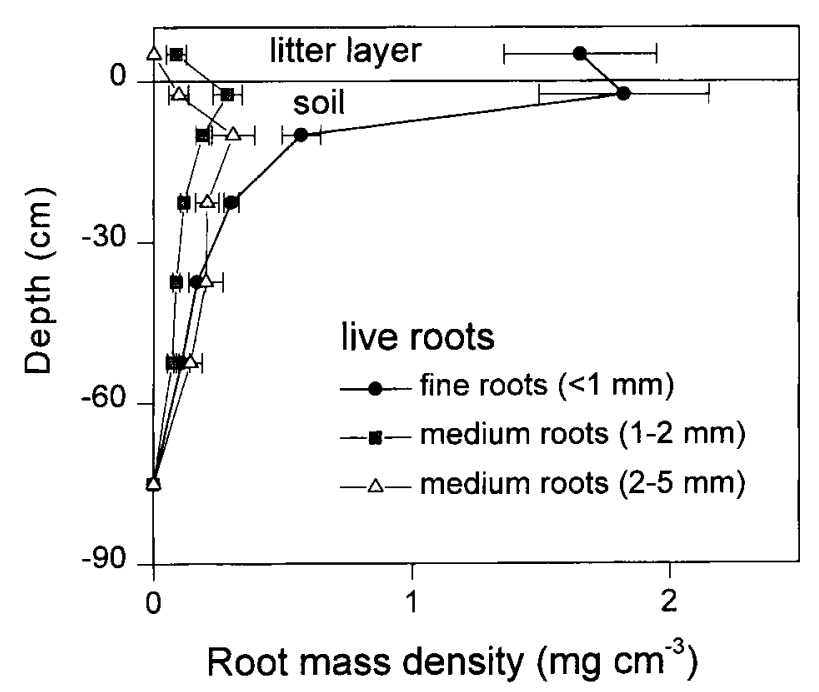

Figure 2. Root mass density of live fine and medium roots as a function of depth in the Brasschaat forest stand. Error bars indicate 1 standard error of the mean $(n=30)$.

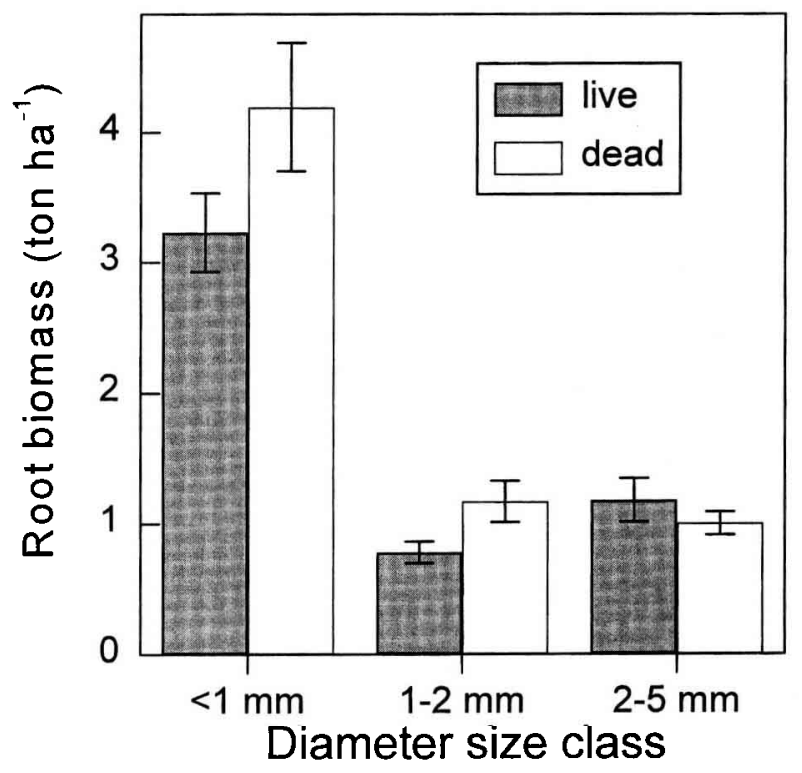

Figure 3. Biomass of both live and dead fine and medium roots in the Brasschaat forest stand. Error bars indicate 1 standard error of the mean $(n=30)$. 


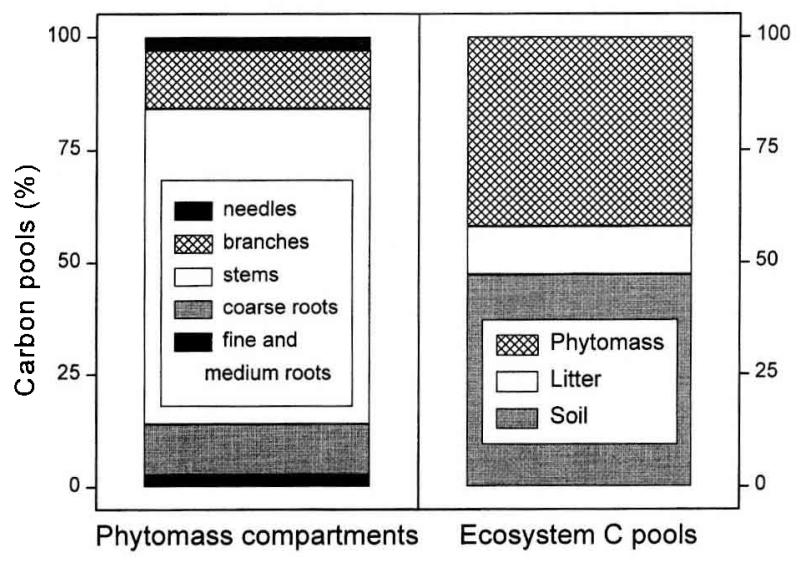

Figure 4. Left: Carbon (C) storage in the phytomass compartments as a percentage of the total amount of $\mathrm{C}$ in the phytomass. Right: $\mathrm{C}$ storage in the phytomass, surface litter and soil as a percentage of the total amount of $\mathrm{C}$ in the forest stand.

\subsection{Belowground pools}

As in most podzols, the $\mathrm{C}$ concentration was very high in the thin uppermost soil layer, and low in all lower horizons (absence of bioturbation). Total $\mathrm{C}$ storage in the mineral soil, to a depth of $1 \mathrm{~m}$ was $114.7 \mathrm{t} \cdot \mathrm{ha}^{-1}$ (tables $I I I$ and $V$ ).

The amount of belowground litter was more or less equal to the amount of live roots (figure 3). A total of 3.0 tha- $1 \mathrm{C}$ was contained in the dead roots (table $\mathrm{V}), 74 \%$ of which was found in the fine $(<1 \mathrm{~mm})$ roots.

This soil organic $\mathrm{C}$ pool contains over $47 \%$ of the total amount of $\mathrm{C}$ in the ecosystem, and exceeds the $\mathrm{C}$ storage in the phytomass.

\section{DISCUSSION}

Stand age and site quality clearly determine the total amount of Scots pine phytomass [43, 47], as well as the allocation and distribution of biomass among different phytomass components. However, trees growing in fertile soils exhibit faster growth rates, thereby reaching the same developmental stage (with similar patterns of allocation) earlier. Therefore, comparison of phytomass allocation requires the examination of stands of similar height and development [47]. The relative contribution of needles and fine roots (and to a lesser degree of branches and coarse roots) decreases with stand age. In addition, the ratio of needles to fine roots decreases [47].

In this study, we found a total phytomass storage of $210 \mathrm{t}^{\text {h ha }}{ }^{-1}$ for a $20.6 \mathrm{~m}$ tall, 69 -year-old Scots pine stand.
Over $70 \%$ of total phytomass was stored in the stems, which represents a large potential long-term $\mathrm{C}$ sink. The proportion of phytomass in the aboveground woody biomass was $83 \%$, which was just within the range reported for various species of pine: 67-84 \% [17]. Our estimate of root biomass ( $14 \%$ of total phytomass) also fell just within the range reported for different pine species: $13-25 \%$ [29]. The observed root:shoot ratio of 0.16 was indeed very low compared to the usually reported mean for coniferous forests: $0.24-0.26[5,6,18]$. This shallow rooting system probably developed because there was no need for the trees to invest in larger and deeper root systems: the subsoil is poor in nutrients and the clay layer prevents the soil from drying out.

Almost $60 \%$ of the total $\mathrm{C}$ in the stand was found in organic matter in soil and litter, which was in agreement with similar Belgian [15] and Dutch [25] forests. Scots pine litter has an acidifying effect on the soil, leading to slow decomposition and accumulation of a thick holorganic horizon on the forest floor, in which large amounts of nutrients are stored. In this stand, $10 \%$ of the total C was stored in the litter layer, whereas almost $50 \%$ was in the soil. In addition to being the largest $\mathrm{C}$ pool, forest soils may store $\mathrm{C}$ in highly recalcitrant molecules, with turnover times of hundreds to thousands of years. Soils may therefore be the most important forest $\mathrm{C}$ pool in the perspective of long-term $\mathrm{C}$ storage.

European forests may sequester between 0.17 and $0.35 \mathrm{Gt}$. C (the equivalent of 10 to $40 \%$ of the anthropogenic $\mathrm{CO}_{2}$ emissions) [19]. As such, in light of the Kyoto protocols, planting trees to sequester $\mathrm{C}$ is likely to contribute to the reduction of net greenhouse gas emissions. An inventory of the terrestrial $\mathrm{C}$ storage in forest systems would help to define the global $\mathrm{C}$ budget and, therefore, aid in the understanding of the source-sink relationships among, and the potential storage capability of, forest ecosystems.

Acknowledgements: This study was funded by the Flemish Community (Afdeling Bos en Groen), and by the EC Environment and Climate Research Programmes Ecocraft and Euroflux. The authors gratefully acknowledge the Institute for Forestry and Game Management for logistic support at the site. We also acknowledge the input of Peter Roskams, of Eric Casella who translated the abstract and of Eva De Bruyn and Nadine Calluy for chemical analysis. We also would like to thank two anonymous reviewers for their constructive comments on an earlier version of this manuscript. I.A.J. is a research assistant and R.C. a research director of the Fund for Scientific Research Flanders (F.W.O.). 


\section{REFERENCES}

[1] Ajtay G.L., Ketner P., Duvigneaud P., Terrestrial biomass production and phytomass, in: Bolin B., Degens E.T., Ketner P. (Eds.), The Global Carbon Cycle, SCOPE 13, John Wiley \& Sons, New York, 1979, pp. 129-182.

[2] Anderson J.M., Ingram J.S.I., Tropical Soil Biology and Fertility - A Handbook of Methods, CAB International, Wallingford, 1993.

[3] Baeyens L., Van Slycken J., Stevens D., Description of the soil profile in Brasschaat, Internal research paper, Institute for Forestry and Game Management, Geraardsbergen, Belgium, 1993.

[4] Becker M., Serre-Bachet F., Modification de la productivité des peuplements forestiers, in : Landmann G. (éd.), Les Recherches en France sur les Ecosystèmes Forestiers. Actualités et Perspectives, Ministère de l'Agriculture et de la Forêt, Paris, 1992, pp. 93-94 (in French).

[5] Cairns M.A., Brown S., Helmer E.H., Baumgardner G.A., Root biomass allocation in the world's upland forests, Oecologia 111 (1997) 1-11.

[6] Cannell M.G.R., World Forest Biomass and Primary Production Data, Academic Press, London, 1982.

[7] Cermak J., Kucera J., Scaling up transpiration data between trees, stands and total watersheds, Silva Carelica 15 (1990) 101-120.

[8] Cermak J., Riguzzi F., Ceulemans R., Scaling up from the individual tree to the stand level in Scots pine. I. Needle distribution, overall crown and root geometry, Ann. Sci. For. 55 (1998) 63-88.

[9] Cottenie A., Verloo M., Kiekens G., Velghe G., Camerlynck R., Chemical Analysis of Plants and Soils, RUG/IWONL, Belgium, 1982.

[10] De Bruyn E., Het bepalen van het totale gehalte aan oplosbare polyfenolen en organische koolstof in de bodem van vier Vlaamse bosecosystemen, thesis, Karel de Grote Hogeschool, Antwerpen, Belgium, 1996 (in Dutch).

[11] Gond V., de Pury D.G.G., Veroustraete F., Ceulemans $R$., Seasonal variation of leaf-area index, leaf chlorophyll and water content scaled up to fAPAR to estimate the carbon balance of a temperate multi-layer, multi-species forest, Tree Physiol. (1999) (in press).

[12] Gosz J.R., Likens G.E., Bormann F.H., Organic matter and nutrient dynamics of the forest and forest floor in the Hubbard Brook Forest, Oecologia 22 (1976) 305-320.

[13] Harrison A.F., Howard P.J.A., Howard D.M., Howard D.C., Hornung M., Carbon storage in forest soils, Forestry 68 (1995) 335-348.

[14] Houghton J.T., Jenkins G.J., Ephraums J.J., Climate Change: the IPCC Scientific Assessment, Cambridge University Press, Cambridge, 1990.

[15] Janssens I.A., Schauvliege M., Samson R., Lust N., Ceulemans R., Studie van de koolstofbalans van, en de koolstofopslag in het Vlaamse bos, Study report UIA/RUG/AMINAL, Ministry of the Flemish Community, 1998 (in Dutch).
[16] Jenkinson D.S., Model estimates of $\mathrm{CO}_{2}$ emissions from soil in response to global warming, Nature 351 (1991) 304-306.

[17] Knight D.H., Vose J.M., Baldwin V.C., Ewel K.C., Grodzinska K., Contrasting patterns in pine forest ecosystems, Ecological Bulletins 43 (1994) 9-19.

[18] Körner C., Biomass fractionation in plants: a reconsideration of definitions based on plant functions, in: Roy J., Garnier E. (Eds.), A Whole Plant Perspective on Carbon-Nitrogen Interactions, SPB Academic, The Hague, 1994, pp. 173-185.

[19] Martin P.H., Valentini R., Jacques M., Fabbri K., Galati D., Quaratino R., Moncrieff J.B., Jarvis P., Jensen N.O., Lindroth A., Grelle A., Aubinet M., Ceulemans R., Kowalski A.S., Vesala T., Keronen P., Malteucci G., Granier A., Berbigier P., Lousteau D., Schulze E.D., Tenhunen J., Rebmann C., Dolman A.J., Elbers J.E., Bernhofer C., Grünwald T., Thorgeirsson H., A new estimate of the carbon sink strength of EU forests integrating flux measurements, field surveys and space observations 0.17-0.35, Ambio 27 (1998) 582-584 Gt(C).

[20] Mohren G.M.J., van den Burg J., Burger F.W., Oterdoom J.H., Fosforgebrek veroorzaakt door hoge stikstoftoevoer in douglasopstanden, Ned. Bosbouw Tijdschrift 58 (1986) 238-245 (in Dutch).

[21] Monserud R.A., Onuchin A.A., Tchebakova N.M., Needle, crown, stem, and root phytomass of Pinus sylvestris stands in Russia, For. Ecol. Manage. 82 (1996) 59-67.

[22] Müller P.E., Recherches sur les formes naturelles de l'humus et leur influence sur la végétation et le sol [translated from Danish], Ann. Sci. Agronom. 1 (1889) 85-423 (in French).

[23] Muys B., The influence of tree species on humus quality and nutrient availability on a regional scale (Flanders, Belgium), in: Nilsson L.O., Huttl R.F., Johansson U.T. (Eds.), Nutrient Uptake and Cycling in Forest Ecosystems, Kluwer Academic Publishers, Dordrecht, 1995, pp. 649-660.

[24] Myneni R.B., Keeling C.D., Tucker C.J., Asrar G., Nemani R.R., Increased plant growth in the northern high latitudes from 1981 to 1991 , Nature 386 (1997) 698-702.

[25] Nabuurs G.J., Mohren G.M.J., Carbon stocks and fluxes in Dutch forest ecosystems, IBN research report no. 93/1, Institute for Forestry and Nature Research, The Netherlands, 1993.

[26] Neirynck J., Results of monitoring of air pollution effects at the experimental site in Brasschaat, Mededelingen van het Instituut voor Bosbouw en Wildbeheer (1999) (in press) (in Dutch).

[27] Neirynck J., De Keersmaeker L., Meettoren Gontrode Bosbodemmeetnet. Eindverslag 1995, IBW - RUG, Belgium, 1996.

[28] Nelson D.W., Sommers L.E., Total carbon, organic carbon, and organic matter, in: Page A.L., Miller R.H., Keeney D.R. (Eds.), Methods of Soil Analysis, Part 2, Chemical and Microbiological Properties, Agronomy Series 9 (2nd edn.), American Society of Agronomy, Madison, WI, 1982, pp. 539-579. 
[29] Nemeth J.C., Dry matter production in young loblolly (Pinus taeda L.) and slash pine (Pinus eliotii Engelm.) plantations, Ecol. Monogr. 43 (1973) 21-41.

[30] Persson H., Root dynamics in a young Scots pine stand in Central Sweden, Oikos 30 (1978) 508-519.

[31] Persson H., Spatial distribution of fine root growth, mortality and decomposition in a young Scots pine stand in Central Sweden, Oikos 34 (1980) 77-87.

[32] Remacle J., Microbial transformations of nitrogen in forests, Oecologia Plantarum 12 (1977) 33-44.

[33] Roberts J., A study of root distribution and growth in a Pinus sylvestris L. (Scots pine) plantation in East Anglia, Plant Soil 44 (1976) 607-621.

[34] Roskams P., Sioen G., Overloop S., Meetnet voor de intensieve monitoring van het bosecosysteem in het Vlaamse Gewest - resultaten 1991-1992, Ministry of the Flemish Community, Institute of Forestry and Game Management, Belgium, 1997 (in Dutch).

[35] Schimel D.S., Terrestrial ecosystems and the carbon cycle, Global Change Biol. 1 (1995) 77-91.

[36] Schimel D.S., Braswell B.H., Holland E.A., McKeown R., Ojima D.S., Painter T.H., Parton W.J., Townsend A.R., Climatic, edaphic, and biotic controls over storage and turnover of carbon in soils, Global Biogeochem. Cycles 8 (1994) 279-293.

[37] Smith P., Powlson D.S., Glendining M.J., Smith J.U., Potential for carbon sequestration in European soils: preliminary estimates for five scenarios using results from long-term experiments, Global Change Biol. 3 (1997) 67-79.

[38] Spiecker H., Mielikänen K., Köhl M., Skovsgaard J.P., Growth Trends in European Forests, Springer-Verlag, Berlin, 1996.

[39] Stanners D., Bourdeau P., Europe's Environment - The Dobris Assessment, European Environment Agency, Copenhagen, 1995.
[40] Sumner M.E., Fey M.V., Noble A.D., Nutrient status and toxicity problems in acid soils, in: Ulrich B., Sumner M.E. (Eds.), Soil Acidity, Springer-Verlag, Berlin/Heidelberg, 1991, pp. 149-182.

[41] Toland D.E., Zak D.R., Seasonal patterns of soil respiration in intact and clear-cut northern hardwood forests, Can. J, For. Res. 24 (1994) 1711-1716.

[42] Ulrich B., Sumner M.E., Soil Acidity, Springer-Verlag, Berlin, 1991.

[43] Usol'tsev V.A., Vanclay J.K., Stand biomass dynamics of pine plantations and natural forests on dry steppe in Kazakhstan, Scand. J. For. Res. 10 (1995) 305-312.

[44] Van den Berge K., Maddelein D., De Vos B., Roskams P., Analyse van de luchtverontreiniging en de gevolgen daarvan op het bosecosysteem, Study Report no. 19 of AMINAL, Ministry of the Flemish Community, 1992 (in Dutch).

[45] van den Burg J., Foliar analysis for determination of tree nutrient status - a compilation of literature data, Internal Report no. 414, De Dorschkamp, The Netherlands, 1985.

[46] van den Burg J., Voorlopige criteria voor de beoordeling van de minerale voedingstoestand van naaldboomsoorten op basis van de naaldsamenstelling in het najaar. Internal Report no. 522, De Dorschkamp, The Netherlands, 1988 (in Dutch)

[47] Vanninen P., Ylitalo H., Sievänen R., Mäkelä A., Effects of age and site quality on the distribution of biomass in Scots pine (Pinus sylvestris L.), Trees 10 (1996) 231-238.

[48] Vogt K.A., Persson H., Measuring growth and development of roots, in: Lassoie J.P., Hinckley T.M. (Eds.), Techniques and Approaches in Forest Tree Ecophysiology, CRC Press, Inc., Boca Raton, FL, 1991, pp. 477-501.

[49] Vogt K.A., Grier G.C., Vogt D.J., Production, turnover, and nutrient dynamics of above- and belowground detritus of world forests, Adv. Ecol. Res. 15 (1986) 303-377. 